\title{
Phenotypic characterisation of Acinetobacter strains of 13 DNA-DNA hybridisation groups by means of the Biolog system
}

\author{
ALEXANDRA T. BERNARDS, L. DIJKSHOORN, J. VAN DER TOORN*, B. R. BOCHNER† \\ and C. P. A. VAN BOVEN
}

Department of Medical Microbiology, Laboratory of Clinical Bacteriology, University Hospital Leiden, PO Box 9600, 2300 RC Leiden, * Kluyver Laboratory for Biotechnology, Julianalaan 67, University of Technology, Delft, The Netherlands and †Biolog Inc., 3938 Trust Way, Hayward, CA 94545, USA

\begin{abstract}
Summary. A collection of 129 Acinetobacter strains belonging to DNA groups (genomic species) 1-14 (1-7 and 10-12 sensu Bouvet and Grimont; 8 and 13-14 sensu Tjernberg and Ursing) were investigated for their ability to oxidise 95 carbon sources in the Biolog system. The strain groupings obtained by cluster analysis with the Biolog software were compared with the results of DNA-DNA hybridisation studies. Strains of DNA groups 1 ( $A$. calcoaceticus), 2 (A. baumannii), 3 and 13 were linked in one cluster, as were DNA groups 4 (A. haemolyticus) and 6, DNA groups 10 and 11, and DNA groups 8 (A. lwoffii) and $12(A$. radioresistens). Strains of DNA group $5(A$. junii) were grouped in a single cluster with one strain of DNA group 4. Strains of DNA groups 7 ( $A$. johnsonii) and 14 formed separate clusters. With the exception of the linkage of DNA groups 8 and 12, these results correlated with classification of reference strains of the DNA groups by DNA-DNA hybridisation, but six strains of four different DNA groups were not allocated to the clusters of their respective DNA groups. In the case of DNA groups 4, 5, 6, 7, 10, 11 and 14, at least one carbon source oxidation test could be used to differentiate them from the other DNA groups.
\end{abstract}

\section{Introduction}

Micro-organisms of the genus Acinetobacter are widespread in nature and have been isolated from environmental and human sources. Many outbreaks of infection with multiresistant strains have occurred ${ }^{1}$ and rapid identification methods are needed to identify these strains. Although the taxonomy of Acinetobacter has been studied extensively, ${ }^{2-5}$ there is as yet no uniform agreement. Bouvet and Grimont ${ }^{4}$ identified 12 genomic species (DNA groups) by DNA-DNA hybridisation. Tjernberg and Ursing ${ }^{5}$ described three additional DNA groups, named 13-15, and the type strain of another species, designated by Nishimura $e t$ $a l^{6}$ as $A$. radioresistens, was found by Tjernberg and $\mathrm{Ursing}^{5}$ to belong to DNA group 12. Concurrently, Bouvet and Jeanjean ${ }^{7}$ delineated five additional DNA groups (named 13-17) among proteolytic strains, and group 13 of this study apparently corresponds to DNA group 14 of Tjernberg and Ursing. ${ }^{5}$

Received 30 June 1994; accepted 1 Aug. 1994.
Carbon source utilisation tests, supplemented with several physiological tests, are unable to discriminate all of the various Acinetobacter DNA groups. ${ }^{4,7-11} \mathrm{~A}$ possible alternative is offered by the Biolog system, which is based on metabolic fingerprinting by determination of carbon source utilisation profiles. Oxidation of substrates, rather than assimilation, leads to reduction of the colourless indicator tetrazolium dye, thereby forming a purple colour. Several recent studies have used the Biolog system to identify various genera and species, ${ }^{12-14}$ but most Acinetobacter strains studied previously ${ }^{14}$ were of unknown genomic group, making conclusions on identification to species level difficult.

The aim of the present study was to characterise and group a collection of Acinetobacter strains of known genomic species by the Biolog system. The grouping of the strains following cluster analysis by the Biolog system was compared with classification based on DNA-DNA hybridisation ${ }^{4,5}$ to evaluate the Biolog system as a possible rapid alternative method for identifying Acinetobacter isolates to the genomic species (DNA group) level. 


\section{Materials and methods}

\section{Bacterial strains}

In total, 129 Acinetobacter strains allocated to DNA groups 1-7 and 10-12 (sensu Bouvet and Grimont), and to DNA groups 8 and 13-14 (sensu Tjernberg and Ursing) by DNA-DNA hybridisation were investigated. Of these, 120 strains, including field isolates from The Netherlands and Sweden and strains from culture collections, have been described previously. ${ }^{5,15}$ Six additional strains, RUH nos. 3212 and 3323 of DNA group 2, nos. 2784 and 3289 of group 3, no. 3198 of group 5 and no. 3206 of group 14 were isolated in Dutch hospitals between 1988 and 1989. These six strains were identified to their DNA groups by DNA-DNA hybridisation with a filter method. ${ }^{16}$ Two strains, UHL no. 286 of DNA group 6 and no. 287 of group 11, originated from the collection of Gerner-Smidt and were kindly provided by Dr I. Tjernberg. Strain LMD 90.19 of DNA group 7 was obtained from the LMD Collection, Delft, and has been described recently by Bonting et al. ${ }^{17}$ Type and reference strains used in this study are shown in table I.

\section{The Biolog system}

The Biolog system (Biolog Inc., Hayward, CA, USA) was used according to the manufacturer's instructions with a few alterations. Briefly, strains stored at $-70^{\circ} \mathrm{C}$ were subcultured on to sheep blood

Table I. Strains of Acinetobacter used in the study

\begin{tabular}{|c|c|c|}
\hline $\begin{array}{l}\text { Genomic } \\
\text { species }\end{array}$ & $\begin{array}{l}\text { Number of } \\
\text { strains }\end{array}$ & Type and reference strains* \\
\hline 1 (A. calcoaceticus) & 8 & ATCC $23055^{\mathrm{T}}, \mathrm{LMD} 22.17$ \\
\hline 2 (A. baumannii) & 36 & $\begin{array}{l}\text { CCUG 19096 }{ }^{\mathrm{T}}(=\mathrm{ATCC} \\
\text { 19606), LMD } 82.54, \text { NCTC } \\
\text { 7844, ATCC } 17904\end{array}$ \\
\hline 3 & 15 & ATCC 19004, LMD 79.41 \\
\hline 4 (A. haemolyticus) & 7 & $\begin{array}{l}\text { ATCC } 17906^{\mathrm{T}}, \text { LMD } 70.9, \\
\text { Gilardi } 2890\end{array}$ \\
\hline 5 (A. junii) & 6 & ATCC $17908^{T}$ \\
\hline 6 & 2 & ATCC 17979 \\
\hline 7 (A. johnsonii) & 9 & ATCC $17909^{\mathrm{T}}$, LMD 90.19 \\
\hline 8 (A. lwoffii $)$ & 13 & NCTC $5866^{\mathrm{T}}$ \\
\hline 10 & 3 & ATCC 17924 \\
\hline 11 & 7 & $\begin{array}{l}\text { CIP } 63.46(=\text { ATCC 11171), } \\
\text { LMD } 81.109\end{array}$ \\
\hline 12 (A. radioresistens) & 7 & $\begin{array}{l}\text { FOR-1 }^{\mathrm{T}}(=\text { IAM 13186), } \\
\text { SEIP } 12.81\end{array}$ \\
\hline 13 & 11 & ATCC 17903 \\
\hline 14 & 5 & ATCC 17905 \\
\hline
\end{tabular}

\footnotetext{
${ }^{T}$, denotes type strain.
}

*ATCC, American Type Culture Collection, Rockville, MD, USA; LMD Collection, Kluyver Laboratory of Biotechnology, Delft, The Netherlands; CCUG, Culture Collection, University of Göteborg Göteborg, Sweden; NCTC, National Collection of Type Cultures, London; CIP, Collection de l'Institut Pasteur, Paris, France; IAM, Institute of Applied Microbiology, University of Tokyo, Tokyo, Japan; SEIP, Service des Entérobactéries de l'Institut Pasteur, Paris, France. agar (Oxoid CM271 with sheep blood $5 \% \mathrm{v} / \mathrm{v}$ ) and incubated at $30^{\circ} \mathrm{C}$. Fresh overnight cultures on Trypticase Soy Agar (BBL; 11043) were used for the tests. Cell suspensions were prepared in pre-warmed saline with a wire loop. Mucoid colonies were harvested with a moistened cotton swab. Inocula were set to the appropriate density, i.e., within the limits of the Biolog GN turbidity standards, with an ATB Densitometer model 1550 (bioMérieux, Benelux B.V., Den Bosch, The Netherlands). The Biolog plates were incubated at $30^{\circ} \mathrm{C}$ and read automatically, by means of the Biolog Microstation plate reader, and visually after incubation for $4 \mathrm{~h}$ and $24 \mathrm{~h}$. Cluster analysis of the oxidation profiles was performed with Biolog's software release 3.01A. The program uses a modified UPGMA method (unweighted pair-group method with arithmetic averages) ${ }^{18}$ which is explained in detail in the Biolog reference manual. Briefly, "distance values", representing in essence the number of tests with discrepant results between two strains, are calculated for all pairs of strains. The structure of the final dendrogram is based on these values, with a distance level of 14 used as a cutting level for separating clusters. This is shown in the dendrogram as a blank line between clusters. If the distance between strains adjacent to these "cut points" is less than 14 , they are joined by a dashed line in the dendrogram at their actual distance value.

\section{Results}

\section{Duration of incubation and reproducibility}

Cluster analysis of the profiles obtained after incubation for $4 \mathrm{~h}$ resulted in a clustering pattern that did not correspond to the recognised DNA groups (data not shown). At $24 \mathrm{~h}$, there was weak colour development in some wells that gave rise to doubtful interpretations on visual reading of the microplates. The 24 -h readings by the plate reader were considered to give the most consistent and objective results, and these were used for further analysis.

The 129 strains were tested in 16 runs. One strain of DNA group 14 was included in every run for testing reproducibility. Numerical analysis of all strains linked the replicates of this strain in one cluster with the other strains of DNA group 14 (data not shown).

\section{Cluster analysis}

Cluster analysis of the oxidation profiles was performed with Biolog's software release 3.01A. Nine clusters (I-IX) were distinguished in the dendrogram (figure). Cluster I contained all strains of DNA groups 1 (A. calcoaceticus), 2 (A. baumannii), 3 and 13, except for the type strain (ATCC 23055) and one other strain of DNA group 1 (LMD 22.17). No subclusters corresponding to DNA groups $1,2,3$ and 13 were distinguished within this cluster. Cluster II contained 


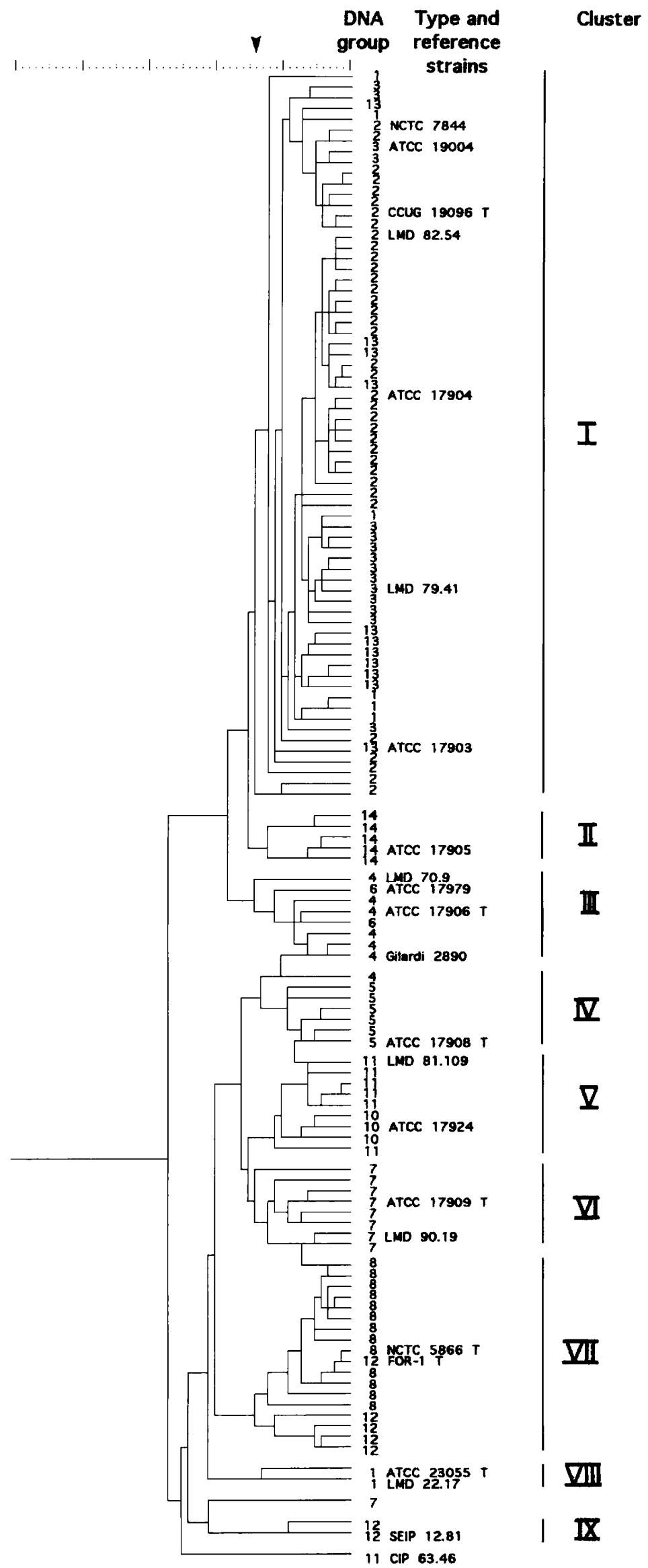

Figure. Dendrogram of numerical analysis of oxidation profiles of 129 Acinetobacter strains, as calculated by Biolog software release 3.01A. Vertical axis shows strains arranged by their DNA group, with type $(T)$ and reference strains (table I) indicated at their appropriate locations. Clusters designated by Roman numerals are based on a "distance level" of 14 , where a "distance level" essentially represents the number of tests with discrepant results between two strains (see text), as indicated by the scale at the top of the figure. 
Table II. Differential characteristics for 13 DNA-DNA hybridisation groups of Acinetobacter based on 34 organic substrates tested in the Biolog system

\begin{tabular}{|c|c|c|c|c|c|c|c|c|c|c|c|c|c|}
\hline \multirow[b]{2}{*}{ Substrate } & \multicolumn{13}{|c|}{$\begin{array}{l}\text { Percentage of strains giving positive reactions in each DNA group } \\
\text { (number of strains tested) and cluster group }\end{array}$} \\
\hline & $\begin{array}{c}1 \\
(8) \\
I\end{array}$ & $\begin{array}{c}2 \\
(36) \\
I\end{array}$ & $\begin{array}{c}3 \\
(15) \\
I\end{array}$ & $\begin{array}{c}13 \\
(11) \\
\text { I }\end{array}$ & $\begin{array}{c}14 \\
(5) \\
\text { II }\end{array}$ & $\begin{array}{c}4 \\
(7) \\
\text { III }\end{array}$ & $\begin{array}{c}6 \\
(2) \\
\text { III }\end{array}$ & $\begin{array}{l}5 \\
(6) \\
\text { IV }\end{array}$ & $\begin{array}{c}10 \\
(3) \\
V\end{array}$ & $\begin{array}{c}11 \\
(7) \\
V\end{array}$ & $\begin{array}{c}7 \\
(9) \\
\text { VI }\end{array}$ & $\begin{array}{c}8 \\
(13) \\
\text { VII }\end{array}$ & $\begin{array}{c}12 \\
(7) \\
\text { VII }\end{array}$ \\
\hline L-Arabinose & 75 & 100 & 100 & 100 & 100 & 86 & 100 & 0 & 33 & 0 & 6 & 8 & 0 \\
\hline L-Fucose & 25 & 0 & 0 & 0 & 0 & 7 & 0 & 0 & 100 & 0 & 0 & 0 & 0 \\
\hline D-Galactose & 63 & 100 & 93 & 100 & 100 & 86 & 100 & 0 & 67 & 0 & 0 & 8 & 0 \\
\hline$\alpha$-D-Glucose & 88 & 100 & 100 & 100 & 100 & 86 & 100 & 0 & 0 & 0 & 0 & 8 & 0 \\
\hline D-Mannose & 75 & 100 & 100 & 100 & 100 & 86 & 50 & 0 & 67 & 14 & 0 & 0 & 0 \\
\hline Citric acid & 75 & 100 & 63 & 91 & 100 & 71 & 100 & 0 & 100 & 14 & 0 & 0 & 0 \\
\hline Formic acid & 75 & 63 & 77 & 100 & 100 & 100 & 75 & 17 & 0 & 14 & 0 & 8 & 0 \\
\hline$\alpha$-Hydroxybutyric acid & 50 & 100 & 83 & 82 & 100 & 0 & 0 & 83 & 100 & 14 & 94 & 0 & 57 \\
\hline$\beta$-Hydroxybutyric acid & 100 & 100 & 100 & 100 & 100 & 100 & 50 & 75 & 100 & 100 & 78 & 0 & 57 \\
\hline$\alpha$-Ketobutyric acid & 75 & 100 & 93 & 100 & 90 & 57 & 100 & 100 & 100 & 100 & 94 & 0 & 43 \\
\hline$\alpha$-Ketoglutaric acid & 37 & 43 & 30 & 9 & 80 & 86 & 100 & 58 & 100 & 100 & 39 & 0 & 79 \\
\hline$\alpha$-Ketovaleric acid & 88 & 100 & 100 & 100 & 40 & 57 & 100 & 0 & 0 & 0 & 33 & 0 & 43 \\
\hline D,L-Lactic acid & 100 & 100 & 100 & 100 & 80 & 0 & 0 & 100 & 100 & 100 & 100 & 62 & 86 \\
\hline Malonic acid & 100 & 100 & 100 & 27 & 60 & 0 & 0 & 0 & 17 & 29 & 22 & 0 & 86 \\
\hline Propionic acid & 69 & 100 & 93 & 91 & 100 & 93 & 75 & 100 & 100 & 100 & 89 & 0 & 14 \\
\hline Quinic acid & 100 & 100 & 87 & 100 & 100 & 100 & 100 & 0 & 67 & 86 & 56 & 0 & 0 \\
\hline D-Saccharic acid & 25 & 86 & 100 & 0 & 0 & 0 & 0 & 0 & 0 & 0 & 11 & 0 & 0 \\
\hline Sebacic acid & 75 & 94 & 100 & 100 & 40 & 21 & 0 & 0 & 100 & 100 & 22 & 73 & 86 \\
\hline Bromo succinic acid & 100 & 100 & 100 & 100 & 100 & 100 & 100 & 100 & 100 & 100 & 100 & 19 & 0 \\
\hline Glucuronamide & 69 & 100 & 100 & 82 & 90 & 86 & 100 & 0 & 33 & 0 & 0 & 8 & 0 \\
\hline D-Alanine & 88 & 100 & 100 & 100 & 30 & 86 & 100 & 17 & 100 & 100 & 100 & 65 & 0 \\
\hline L-Asparagine & 100 & 100 & 100 & 100 & 100 & 100 & 100 & 100 & 100 & 71 & 100 & 0 & 57 \\
\hline L-Aspartic acid & 100 & 100 & 80 & 100 & 10 & 29 & 100 & 17 & 83 & 71 & 89 & 0 & 29 \\
\hline L-Histidine & 100 & 100 & 100 & 100 & 100 & 86 & 100 & 67 & 100 & 100 & 0 & 0 & 0 \\
\hline Hydroxy L-proline & 12 & 100 & 7 & 55 & 0 & 14 & 0 & 0 & 0 & 0 & 0 & 0 & 0 \\
\hline L-Leucine & 75 & 100 & 87 & 100 & 40 & 86 & 100 & 33 & 0 & 0 & 6 & 0 & 29 \\
\hline L-Phenylalanine & 100 & 94 & 80 & 100 & 100 & 0 & 0 & 0 & 0 & 0 & 0 & 0 & 43 \\
\hline L-Serine & 75 & 42 & 27 & 27 & 20 & 86 & 100 & 33 & 67 & 25 & 0 & 0 & 0 \\
\hline L-Pyroglutamic acid & 100 & 100 & 100 & 100 & 100 & 0 & 0 & 0 & 100 & 93 & 100 & 0 & 57 \\
\hline D,L-Carnitine & 0 & 86 & 73 & 91 & 90 & 0 & 0 & 0 & 100 & 93 & 11 & 0 & 29 \\
\hline$\gamma$-Amino butyric acid & 100 & 100 & 100 & 100 & 0 & 100 & 0 & 67 & 100 & 86 & 67 & 31 & 86 \\
\hline Urocanic acid & 100 & 90 & 73 & 82 & 40 & 0 & 50 & 8 & 0 & 0 & 11 & 0 & 0 \\
\hline Putrescine & 100 & 100 & 100 & 91 & 0 & 0 & 0 & 0 & 0 & 0 & 0 & 0 & 71 \\
\hline 2-Amino ethanol & 25 & 0 & 27 & 0 & 100 & 0 & 0 & 0 & 100 & 79 & 67 & 0 & 0 \\
\hline
\end{tabular}

all five strains of DNA group 14. Cluster III comprised six of the seven strains of DNA group $4(A$. haemolyticus) and the two strains of DNA group 6 . Cluster IV contained the remaining DNA group 4 strain and the six strains of DNA group 5 (A. junii). However, this DNA group 4 strain was linked to a DNA group 4 strain in cluster III at a higher similarity level than to the strains of DNA group 5. Cluster V comprised the three DNA group 10 strains and six of the eight DNA group 11 strains. Two small subclusters were distinguished within this cluster, one with five strains of DNA group 11, and the other with the three DNA group 10 strains. One strain of DNA group 11 was equally distant from these two subclusters. Cluster VI contained eight of the nine strains of DNA group 7 (A. johnsonii). Cluster VII contained all strains of DNA group 8 ( $A$. lwoffi $)$ and five strains of DNA group 12 (A. radioresistens). Two subclusters were distinguished, one with all DNA group 8 strains and the type strain of DNA group 12, and the other with four strains of DNA group 12. Cluster VIII comprised two strains of DNA group 1 ( $A$. calcoaceticus), both of which, including the type strain of DNA group 1, were isolated by Beyerinck early this century. Cluster IX contained two strains of DNA group 12. One strain of DNA group 7 and one strain of DNA group 11 remained unclustered.

\section{Reactions of the 13 DNA groups with 95 carbon sources}

Positive oxidation reactions according to the automatic reader for the 13 DNA groups with the 95 carbon sources were scored after incubation for $24 \mathrm{~h}$. Tests were considered useful for discriminating DNA groups if there was a $100 \%$ difference in the occurrence of positive reactions for strains from at least two groups. Thirty-four tests met this criterion (table II). Of the remaining 61 tests, two were positive for all strains and 16 were negative for all strains (table III). With 33 tests, positive reactions were obtained for between 0 and $71 \%$ of strains, depending on the DNA group, while eight tests were positive with $8-100 \%$ of strains. Two tests were negative for three and two strains respectively (table III).

Tests with the best capacity for discriminating 
Table III. Tests not considered to discriminate between DNA groups

Positive for all strains

Tween 40, Tween 80

Negative for all strains

Glycogen, $N$-acetyl-D-galactosamine, $N$-acetyl-D-glucosamine, adonitol, D-arabitol, lactulose, maltose, D-psicose, D-raffinose, Lrhamnose, D-sorbitol, D-galactonic acid lactone, phenyl ethylamine, glycerol, D,L- $\alpha$-glycerol phosphate, glucose-1phosphate

Positive reactions for $0-71 \%$ of strains tested in each DNA group $\alpha$-Cyclodextrin, dextrin, cellobiose, $i$-erythritol, $\mathrm{D}$-fructose, gentobiose, $m$-inositol, $\alpha$-D-lactose, D-mannitol, D-melibiose, $\beta$ methyl-D-glucoside, sucrose, D-trehalose, turanose, xylitol, Dgalacturonic acid, D-gluconic acid, D-glucosaminic acid, Dglucuronic acid, $\gamma$-hydroxybutyric acid, $p$-hydroxyphenylacetic acid, itaconic acid, alaninamide, L-alanyl glycine, glycyl-Laspartic acid, glycyl-L-glutamic acid, L-ornithine, D-serine, $\mathbf{L}-$ threonine, inosine, uridine, thymidine, glucose-6-phosphate

Positive reactions for $8-100 \%$ of strains tested in each DNA group Mono-methyl succinate, cis-aconitic acid, succinic acid,

succanimic acid, L-alanine, L-glutamic acid, L-proline, 2,3butanediol

Negative for a few strains

Methylpyruvate*, acetic acid $\dagger$

*Negative for two strains of DNA group 4 and one strain of DNA group 13.

$\dagger$ Negative for one strain of DNA group 1 and one strain of DNA group 12 .

Table IV. Summary of test substrates used to discriminate DNA groups 1, 2, 3 and 13

\begin{tabular}{lrrrr}
\hline & \multicolumn{3}{c}{$\begin{array}{c}\text { Percentage of strains giving positive } \\
\text { reactions in each DNA group } \\
\text { (number of strains tested) }\end{array}$} \\
\cline { 2 - 5 } Substrate & 1 & 2 & 3 & 13 \\
& $(8)$ & $(36)$ & $(15)$ & $(11)$ \\
\hline Malonic acid & 100 & 100 & 100 & 27 \\
D-Saccharic acid & 25 & 86 & 100 & 0 \\
Hydroxy L-proline & 12 & 100 & 7 & 55 \\
D,L-Carnitine & 0 & 86 & 73 & 91 \\
& & & & \\
\hline
\end{tabular}

Table V. Summary of test substrates used to discriminate DNA groups 8 and 12

\begin{tabular}{lcc}
\hline & $\begin{array}{c}\text { Percentage of strains giving positive } \\
\text { reactions in each DNA group } \\
\text { (number of strains tested) }\end{array}$ \\
\cline { 2 - 3 } Substrate & 8 & 12 \\
& $(13)$ & $(7)$ \\
\hline$\alpha$-Ketoglutaric acid & 0 & 79 \\
Malonic acid & 0 & 86 \\
L-Glutamic acid & 8 & 100 \\
Putrescine & 0 & 71 \\
\hline
\end{tabular}

between DNA groups 1, 2, 3 and 13 are summarised in table IV. The only test substrate that differentiated DNA group 3 from group 13 clearly was D-saccharic acid. DNA group 14 (cluster II ; figure) linked closest to DNA groups 1, 2, 3 and 13 (cluster I), but could be distinguished from these groups by between two and four tests (table II).

Between DNA groups 4 and 6 (cluster III; figure), oxidation of $\gamma$-amino butyric acid made a clear distinction (table II). Oxidation tests discriminating DNA groups 4 and 5 (cluster IV; figure) were D,Llactic acid and quinic acid, but seven additional tests (L-arabinose, D-galactose, $\alpha$-D-glucose, D-mannose, formic acid, $\alpha$-hydroxybutyric acid and glucuronamide) showed $83-86 \%$ differences in the percentage of strains giving positive reactions, thereby adding to the distinction of these two groups (table II). DNA groups 10 and 11 , linked in cluster $\mathrm{V}$ (figure) were separated by the L-fucose test. The citric acid and $\alpha$ hydroxybutyric acid tests added to the discrimination of these groups as, in both cases, all DNA group 10 strains and only one (14\%) of seven strains of DNA group 11 were positive (table II).

No tests distinguished DNA group 8 from DNA group 12 clearly. For $\alpha$-ketoglutaric acid, malonic acid, L-glutamic acid and putrescine, the differences in the percentage of strains giving positive reactions were $79 \%, 86 \%, 92 \%$ and $71 \%$, respectively (table V). Two strains of DNA group 12 were linked separately (cluster IX; figure). Cluster analysis was repeated on all strains excluding the two strains in cluster IX, but no improvement in separating DNA groups 8 and 12 was found (data not shown).

\section{Identification to genus and DNA group level by Biolog software release $3.01 \mathrm{~A}$}

Although grouping based on Biolog's "breathprints" was the primary purpose of the study, the data were also used to evaluate the then current database release (3.01A) of Biolog's software for its ability to identify the strains. Automated readings after incubation for $4 \mathrm{~h}$ showed correct identification to the genus level for $10 \%$ of strains, while no identification was given for $89 \%$ of strains. After incubation for $24 \mathrm{~h}, 109(84.5 \%)$ of the 129 strains were identified as belonging to the genus Acinetobacter (table VI), and 58 $(45 \%)$ of these strains were identified to the correct DNA group. Of the remaining 20 strains, one $(0 \cdot 8 \%)$ was wrongly identified to the genus Psychrobacter while no identification was reached for the remaining 19 strains $(14.7 \%)$. Visual readings after incubation for $24 \mathrm{~h}$ identified $80.7 \%$ of the strains to the genus level and $45 \%$ to the correct DNA group, while no identification was reached for $14.7 \%$ of strains. Six strains $(4 \cdot 7 \%)$ were wrongly identified to other genera.

\section{Discussion}

Identification of oxidative micro-organisms by their catabolic enzymes was first described by den Dooren de Jong ${ }^{19}$ who, while studying the nutritional versatility of soil and water bacteria with over 200 organic compounds, distinguished separate groups among the 
Table VI. Identification of 129 Acinetobacter strains by Biolog software release 3.01A

\begin{tabular}{lccccccccccc}
\hline & \multicolumn{8}{c}{ Number of strains of each DNA group identified to the level shown } \\
(number of strains tested)
\end{tabular}

aerobic pseudomonads that were useful for taxonomic purposes. Baumann et al. ${ }^{2}$ used the same principle to characterise strains of the genus Acinetobacter. Following the identification of at least 17 DNA groups within the genus Acinetobacter by DNA-DNA hybridisation,,$^{4,5,7}$ utilisation of carbon sources has been studied as a tool for the possible phenotypic identification of the different groups. ${ }^{4,7,9-11}$ Although several DNA groups could be distinguished, this approach was unsatisfactory for discriminating the DNA groups that were closely related genetically.

The present study demonstrated that the Biolog system resulted in the clustering of DNA group $1(A$. calcoaceticus) with groups 2 (A. baumannii), 3 and 13 (cluster I); of DNA group 4 (A. haemolyticus) with group 6 (cluster III); of DNA group 10 with group 11 (cluster $\mathrm{V}$ ); and in the identification of separate clusters for DNA groups 7 (cluster VI) and DNA group 14 (cluster II). These results were in overall agreement with previous DNA-DNA relatedness studies, ${ }^{4,5}$ except for the close linking of DNA groups 8 and 12 which has not been shown previously by DNA homology studies.

The discrimination of DNA groups 1, 2, 3 and 13 has been achieved by ribotyping, ${ }^{20}$ but this method is beyond the skills of most routine laboratories. The separation of these DNA groups on the basis of utilisation of organic compounds does not seem possible at the moment. ${ }^{4,9,10}$ Growth at $44^{\circ} \mathrm{C}$ has been shown to distinguish DNA group 2 from DNA groups 1 and $3,{ }^{4,9}$ and $D$-asparagine assimilation differentiates DNA group 1 from DNA groups 2 and 3. ${ }^{10}$ The present paper adds D-saccharic acid oxidation to the characteristics distinguishing DNA group 3 from 13. The two aberrant strains of DNA group $1(A$. calcoaceticus) in the present study (the type strain ATCC 23055 and strain LMD 22.17; cluster VIII, figure) were described in 1911 by Beyerinck. Both of these strains showed atypical results in the study of Baumann et al., ${ }^{2}$ and it has been suggested that cultivation of the strains under laboratory conditions for many years might have caused the acquisition of deviant traits.

None of the tests used in the study of Gerner-Smidt et al. ${ }^{9}$ separated DNA group 4 completely from DNA group 6. The best distinguishing trait was found to be growth on 4-aminobutyrate (DNA group 4, 95\%; DNA group 6, $0 \%$ ). In the present study, oxidation of $\gamma$-amino butyric acid (=4-aminobutyrate) separated the groups clearly, although only a limited number of strains of DNA group 4 were tested.

According to Bouvet and Grimont, ${ }^{4}$ DNA groups 10 and 11 can be separated by testing for glucose acidification. This finding was confirmed by GernerSmidt et al. ${ }^{9}$ and Kämpfer et al. ${ }^{10}$ who also found growth at $37^{\circ} \mathrm{C}$ to be a distinguishing test. In the present study, oxidation of L-fucose was found to be a discriminating test. However, none of the strains used by Kämpfer $e t$ al. ${ }^{10}$ used this compound for growth. This discrepancy may be explained by the fact that the Biolog system tests for oxidation rather than growth.

DNA homology studies have not shown a close relationship between DNA groups 8 and 12. In the studies of Bouvet and Grimont ${ }^{4}$ and Gerner-Smidt $e t$ $a l .,{ }^{9}$ groups 8 and 12 were easily separated phenotypically. However, Kämpfer et al..$^{10}$ found the two groups to be related more closely to each other, and to the one strain of DNA group 15, than to any of the other DNA groups. The only discriminating test in their study, L-leucine assimilation, was positive for all DNA group 12 strains, whereas in the present study only $29 \%$ of DNA group 12 strains oxidised this substrate and no clearly discriminating tests were found for DNA groups 8 and 12 . At best, four tests $(\alpha-$ ketoglutaric acid, malonic acid, L-glutamic acid and putrescine) showed differences in the percentage of strains from the two groups giving positive reactions of $71 \%-92 \%$. The results obtained with L-phenylalanine, malonate, L-leucine (table II) and 2,3butanediol (not shown) differed considerably from those of Bouvet and Grimont ${ }^{4}$ in that no discriminating potential was found in the present study. The type strain of DNA group 12 appeared to be closer phenotypically to the strains of DNA group 8 than to the strains of DNA group 12. Gerner-Smidt et al. ${ }^{9}$ also found that this strain behaved atypically.

In the present study, $109(84.5 \%)$ strains were identified correctly by Biolog to the genus level, which is in accordance with the $82.8 \%$ finding of Knight et al. ${ }^{14}$ Of the 51 strains identified to an 
incorrect DNA group, 42 belonged to DNA groups 1 , 2,3 or 13 . Therefore, given the close relationship of these DNA groups, we support the suggestion of Tjernberg and Ursing ${ }^{5}$ and Gerner-Smidt et al. ${ }^{9}$ that these DNA groups should be linked in a "complex" to help microbiologists in their daily practice to identify strains unambiguously.

Phenotypic identification of Acinetobacter to the genomic species level is currently unsatisfactory, and the various systems described ${ }^{8,10}$ are not applied widely. Commercial systems are, in principle, within reach of any laboratory worldwide, and might, there-

\section{References}

1. Bergogne-Bérézin E, Joly-Guillou ML, Vieu JF. Epidemiology of nosocomial infections due to Acinetobacter calcoaceticus. $J$ Hosp Infect 1987; 10: 105-113.

2. Baumann P, Doudoroff M, Stanier RY. A study of the Moraxella Group; II. oxidative-negative species (genus Acinetobacter). J Bacteriol 1968; 95: 1520-1541.

3. Henriksen SD. Moraxella, Acinetobacter, and the Mimiae. Bacteriol Rev 1973; 37: 522-561.

4. Bouvet PJM, Grimont PAD. Taxonomy of the genus Acinetobacter with the recognition of Acinetobacter baumannii sp. nov., Acinetobacter haemolyticus sp. nov., Acinetobacter johnsonii sp. nov., and Acinetobacter junii sp. nov, and emended descriptions of Acinetobacter calcoaceticus and Acinetobacter lwoffii. Int J Syst Bacteriol 1986; 36: $228-240$.

5. Tjernberg I, Ursing J. Clinical strains of Acinetobacter classified by DNA-DNA hybridization. APMIS 1989; 97: 595-605.

6. Nishimura Y, Ino Y, Iizuka H. Acinetobacter radioresistens sp. nov. isolated from cotton and soil. Int $J$ Syst Bacteriol 1988; 38: 209-211.

7. Bouvet PJM, Jeanjean S. Delineation of new proteolytic genomic species in the genus Acinetobacter. Res Microbiol 1989; 140: 291-299.

8. Bouvet PJM, Grimont PAD. Identification and biotyping of clinical isolates of Acinetobacter. Ann Inst Past/Microbiol 1987; 138: $569-578$.

9. Gerner-Smidt P, Tjernberg I, Ursing J. Reliability of phenotypic tests for identification of Acinetobacter species. J Clin Microbiol 1991; 29: 277-282.

10. Kämpfer P, Tjernberg I, Ursing J. Numerical classification and identification of Acinetobacter genomic species. $J$ Appl Bacteriol 1993; 75: 259-268.

11. Soddell JA, Beacham AM, Seviour RJ. Phenotypic identi- fore, serve as a reference system. Construction of data bases founded on well-defined strains is of paramount importance for correct identification by these systems. The clustering pattern obtained in the present study indicates that incorporation of the data into the Biolog software will improve identification of Acinetobacter species by the system. The results also suggest that the Biolog system may be helpful in grouping strains as part of taxonomic investigations.

We thank Ms Tanny J. K. van der Reijden for technical assistance. fication of non-clinical isolates of Acinetobacter species. $J$ Appl Bacteriol 1993; 74: 210-214.

12. Miller JM, Rhoden DL. Preliminary evaluation of Biolog, a carbon source utilization method for bacterial identification. J Clin Microbiol 1991; 29: 1143-1147.

13. Klingler JM, Stowe RP, Obenhuber DC, Groves TO, Mishra SK, Pierson DL. Evaluation of the Biolog automated microbial identification system. Appl Environ Microbiol 1992; 58: 2089-2092.

14. Knight GC, McDonnell SA, Seviour RJ, Soddell JA. Identification of Acinetobacter isolates using the Biolog identification system. Lett Appl Microbiol 1993; 16: 261-264.

15. Dijkshoorn L, Tjernberg I, Pot B, Michel MF, Ursing J, Kersters K. Numerical analysis of cell envelope protein profiles of Acinetobacter strains classified by DNA-DNA hybridization. Syst Appl Microbiol 1990; 13: 338-344.

16. Tjernberg I, Lindh E, Ursing J. A quantitative bacterial dot method for DNA-DNA hybridization and its correlation to the hydroxyapatite method. Curr Microbiol 1989; 18: $77-81$.

17. Bonting CFC, Willemsen BMF, Akkermans-van Vliet $\mathrm{W}$, Bouvet PJM, Kortstee GJJ, Zehnder AJB. Additional characteristics of the polyphosphate-accumulating Acinetobacter strain $210 \mathrm{~A}$ and its identification as Acinetobacter johnsonii. FEMS Microbiol Ecol 1992; 102: $57-64$.

18. Sneath PHA. Computer taxonomy. In: Norris JR, Ribbons DW (eds) Methods in microbiology, vol 7A. London, Academic Press. 1972: 29-98.

19. den Dooren de Jong LE. Bijdrage tot de kennis van het mineralisatieproces. (Thesis). Nijgh \& van Ditmar's uitgevers Mij. Rotterdam 1926.

20. Gerner-Smidt P. Ribotyping of the Acinetobacter calcoaceticusAcinetobacter baumannii complex. J Clin Microbiol 1992; 30: $2680-2685$. 